\title{
Kesulitan Guru Biologi Dalam Melaksanakan Pembelajaran Jarak Jauh Di SMAN 1 Paciran
}

\section{Patekur $^{1 *}$, Mu'jizatin Fadiana ${ }^{2}$}

${ }^{1}$ Program Studi Magister Pendidikan Biologi, Universitas PGRI Ronggolawe Tuban, Indonesia, dan SMA Negeri 1 Paciran Lamongan, Indonesia

${ }^{2}$ Universitas PGRI Ronggolawe Tuban, Indonesia

*Email: alfaruq1924@gmail.com

\section{Info Artikel}

Diterima: 6 April 2021

Direvisi: 18 Oktober 2021

Diterima untuk diterbitkan: 28 Oktober 2021

Keywords:
Kesulitan,
Pembelajaran biologi,
Pembelajaran jarak jauh

\begin{abstract}
Abstrak
Tujuan penelitian ini untuk mengeksplorasi dan mendeskripsikan kesulitan yang dihadapi guru biologi dalam merencanakan, melaksanakan, dan mengevaluasi pembelajaran jarak jauh pada jenjang SMA. Penelitian ini menggunakan pendekatan penelitian kualitatif deskriptif. Subjek penelitian diambil dengan teknik purposive sampling sebanyak 2 guru biologi jenjang SMA. Data penelitian dengan teknik wawancara dan kuesioner terbuka. Kemudian dianalisis melalui tahapan reduksi data, display data, dan verifikasi dan penarikan kesimpulan. Keabsahan data diuji dengan triangulasi metode antara wawancara dan kuesioner terbuka. Hasil penelitian ini menunjukkan bahwa kesulitan subjek penelitian dalam merencanakan pembelajaran jarak jauh antara lain: keterbatasan alokasi waktu, kesulitan dalam mempersiapkan media pembelajaran yang efektif; kendala jaringan internet saat mempersiapkan pembelajaran. Dalam melaksanakan pembelajaran jarak jauh subjek penelitian mengalami kesulitan dalam memantau dan mengontrol aktivitas siswa selama pembelajaran, membangun komunikasi dengan siswa yang pasif saat pembelajaran. Sedangkan kesulitan pada tahap evaluasi adalah kesulitan dalam penilaian sikap, terutama kejujuran dan penilaian keterampilan yang tidak ideal.
\end{abstract}

(C) 2021 Universitas Bengkulu. This is an open-access article under the CC-BY license (https://creativecommons.org/licenses/by/4.0)

\section{PENDAHULUAN}

Kado akhir tahun 2019 hingga awal tahun 2020 bagi masyarakat dunia adalah muncul infeksi virus Corona dengan cepat di Wuhan, China. Virus Corona di Wuhan, yang kemudian disebut Covid-19 tersebar dengan cepat dan masif di beberapa negara. World Health Organization (WHO) telah mengumumkan bahwa sejak tanggal 11 Maret 2020 Covid-19 sebagai pandemi. Wabah Covid-19 telah memakan banyak korban manusia. Berdasarkan laporan WHO pada tanggal 
17 Januari 2021, ada enam wilayah yang menjadi pemecah rekor jumlah yang terkonfirmasi Covid19 dan kasus kematian. Enam wilayah tersebut secara urut dari tinggi ke rendah adalah Amerika, Eropa, Asia Tenggara, Timur Mediteranian, Afrika, dan Pasifik Barat. Jumlah total kasus terpapar 93.212.287 orang dan jumlah kematian total 2.014.957 orang dari enam wilayah tersebut. Jumlah kasus Covid-19 dan kematian di Indonesia menduduki peringkat ke 2 setelah India di Wilayah Asia Tenggara (WHO, 2020). Indonesia termasuk negara yang terpapar Covid-19 sejak bulan Maret 2020.

Wabah Covid-19 telah berlangsung satu tahun di dunia, termasuk di Indonesia telah melewati sebelas bulan. Dampak pandemik Covid-19 dirasakan banyak negara pada semua bidang kehidupan, termasuk bidang pendidikan. Pelaksanaan pendidikan di sekolah mulai tingkat taman kanak-kanak sampai perguruan tinggi tidak bisa dilaksanakan secara tatap muka, kecuali wilayah yang tidak terkena kebijakan Pemberlakuan Pembatasan Kegiatan Masyarakat (PPKM). Bahkan UNESCO menyatakan bahwa ada 300 juta siswa yang terancam pendidikannya disebabkan wabah virus corona (Handoyo, 2020). Pandemi ini, merubah kebijakan dunia pendidikan di Indonesia, baik terkait regulasi pendidikan, keterlaksanaan kegiatan pembelajaran, dan evaluasi pembelajaran.

Pendidikan dan pengajaran merupakan kebutuhan dasar bagi masyarakat. Keterlaksanaan pendidikan dan pengajaran merupakan tanggung jawab negara. Pemerintah bersinergi dengan pemerintah daerah untuk terus melakukan upaya pemenuhan kebutuhan dasar pendidikan masyarakat (Kemendikbud, 2018). Oleh karena itu, pendidikan dan pengajaran harus berjalan sesuai dengan situasi, kondisi, dan juga kebijakan dari pemerintah. Situasi dan kondisi pandemi Covid-19 ini mengharuskan bagi guru untuk meningkatkan inovasi dan kreativitas dalam merencanakan, melaksanakan, dan melakukan evaluasi pembelajaran. Fakta di lapangan menunjukkan bahwa sebagian guru Biologi SMA Negeri 1 Paciran menyampaikan keluhan akan keberatan dalam melaksanakan pembelajaran jarak jauh pada kesempatan pendampingan Musyawarah Guru Mata Pelajaran (MGMP) Biologi SMA Negeri 1 Paciran pada November 2020. Hal ini juga dikuatkan dengan survei yang dilakukan oleh Ditjen Guru dan Tenaga Kependidikan Kemendikbud yang menyatakan bahwa $60 \%$ guru masih mengalami kesulitan melakukan pembelajaran jarak jauh (Radarcirebon, 2020).

Beberapa penelitian terkait pembelajaran jarak jauh telah dilakukan oleh banyak peneliti. Pada sekolah dasar, pelaksanaan pembelajaran daring tidak cocok, karena pada sekolah tingkat ini, pembelajarann masih berpusat pada guru (teacher center). Tujuan pembelajaran tidak dapat tersampaikan dengan sepenuhnya kepada peserta didik (Anggianita et al., 2020). Pembelajaran daring pada tingkat Madrasah Ibtidaiyah dapat menambah kesulitan bagi orang tua, yakni orang tua harus menyediakan waktu yang lebih untuk mendampingi anak-anaknya. Sedangkan bagi guru menjadi tantangan tersendiri yang harus belajar teknologi dan menyiapkan bahan ajar yang lebih rumit (Sari, 2020). Pembelajaran daring di Perguruan Tinggi menunjukkan kendala kelemahan pengawasan aktivitas mahasiswa, sinyal lemah di daerah pelosok, dan membutuhkan biaya kuota yang cukup mahal (Sadikin \& Hamidah, 2020). Penguasaan teknologi dan biaya yang mahal sebagai kendala pelaksanaan pembelajaran daring bagi guru, orang tua, dan siswa (Mastura \& Santaria, 2020). Kesulitan guru dalam pembelajaran online tingkat sekolah dasar negeri adalah pada penentuan jenis penilaian, penyampaian materi, dan pelaksanaan evaluasi (Ariesca et al., 2021). Kesulitan mendasar bagi mahasiswa matematika saat pembelajaran daring dari sisi jaringan internet, keterbatasan fitur aplikasi pembelajaran daring, dan pelayanan pembelajaran (Hutauruk \& Sidabutar, 2020). Saat pembelajaran daring, guru mengalami kesulitan aplikasi pembelajaran, jaringan internet dan gawai, pengelolaan, penilaian, dan pengawasan pembelajaran (lia dwi jayanti, 2020). Bagi guru praktek lapangan tingkat SMP mengalami kesulitan susah internet, siswa tidak paham materi dan tidak mengumpulkan tugas, dan siswa tidak bisa praktek saat pembelajaran daring (Karmala, 2021). Kendala pembelajaran biologi secara daring di tingkat SMP adalah kesulitan memahami materi dan jaringan internet (Santosa \& Marina, 2020). Bagi guru mengalami kesulitan pembelajaran daring terkait media, sarana prasarana, pengembangan kreativitas, memotivasi dan penanaman sikap pada siswa (Sae \& Sihotang, 2020). Kesulitan guru terhadap 
kelengkapan sarana dan prasarana bagi guru IPS saat pembelajaran daring (Budiaman, 2017). Hambatan pembelajaran daring dialami orang tua yang harus banyak menyediakan waktu untuk mendampingi anaknya. Hambatan juga dialami guru yang harus melek teknologi dan kreatif dalam melaksanakan pembelajaran untuk dapat menghilangkan kebosanan siswa (Anugrahana, 2020).

Hanya saja penelitian tersebut terkait kesulitan, hambatan, dan kendala guru biologi saat pelaksanaan pembelajaran jarak jauh di masa pandemi atau penilaian sikapnya. Oleh karena itu, masih dibutuhkan penelitian yang dapat mengeksplorasi kesulitan guru biologi secara komprehensif, yakni mulai perencanaan, pelaksanaan pembelajaran, dan penilaian pembelajaran daring dengan jarak jauh.

Berdasarkan pemaparan di atas, penelitian ini bermaksud untuk mengeksplorasi dan mendeskripsikan kesulitan-kesulitan yang dihadapi guru biologi dalam merencanakan, melaksanakan, dan mengevaluasi pembelajaran jarak jauh pada jenjang SMA.

\section{METODE}

Jenis penelitian ini adalah penelitian kualitatif deskriptif. Metode penelitian kualitatif digunakan untuk memahami permasalahan-permasalahan sosial sentral untuk dideskripsikan dan diungkapkan (Raco, 2018). Penelitian deskriptif merupakan kelanjutan dari penelitian eksploratif, bahkan lebih luas darinya, karena tidak hanya mengetahui tentang suatu pertanyaan apa, tetapi tentang pertanyaan bagaimana (Gulo, 2002). Tujuan penelitian kualitatif adalah pertama, untuk memvisualkan dan mengeksplorasikan tentang sesuatu. Kedua, untuk memvisualkan dan memaparkan tentang sesuatu (Siyoto \& Sodik, 2015). Penelitian deskriptif digunakan untuk memaparkan dan menvisualisasikan faktor-faktor yang terjadi dengan kata-kata, baik masa lalu maupun masa sekarang. Sementara itu, objek penelitian ini difokuskan pada permasalahan pembelajaran biologi secara daring atau jarak jauh di masa Covid-19. Penelitian ini dilaksanakan pada bulan Januari semester genap Tahun Pelajaran 2020/2021.

Subjek penelitian ini diambil dengan teknik purposive sampling. Teknik ini dengan menentukan kriteria khusus dan sesuai dengan tujuan dari peneliti (Priyono, 2008). Subjek penelitian ini sejumlah 2 guru Biologi tingkat SMA yang berinisial AK dan SF. Teknik pengambilan data penelitian ini menggunakan teknik wawancara langsung ke responden dan kuesioner terbuka secara online dengan aplikasi google form. Analisis data penelitian ini meliputi tiga tahapan yakni, pertama reduksi data. Reduksi data merupakan tahapan pengumpulan informasi data dari hasil wawancara dan pengisian kuesioner terbuka, kemudian dikelompokkan datanya. Kedua, display data. Pada tahapan ini merupakan penyortiran data yang dibutuhkan dan pembuangan data yang tidak dibutuhkan. Ketiga, penarikan dan verifikasi kesimpulan. Tahapan ini merupakan tahapan interpretasi terhadap data penelitian untuk ditarik sebuah kesimpulan berdasarkan fenomena tertentu. Tiga tahap analisis data dapat dilihat gambar.

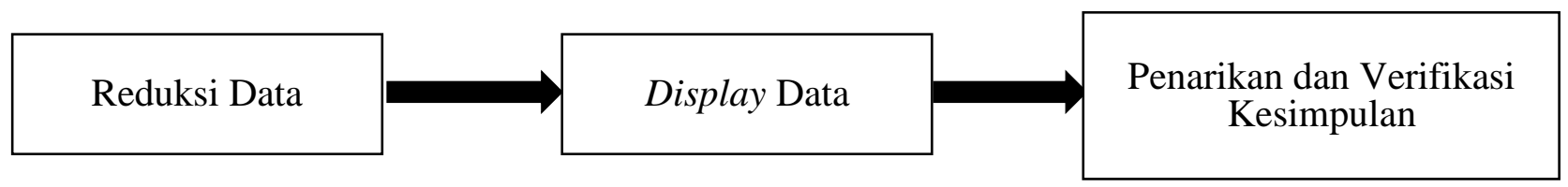

Gambar 1. Tiga Tahapan Analisis Data

Sementara itu, teknik keabsahan data penelitian ini menggunakan triangulasi metode, yakni antara metode wawancara dan kuesioner terbuka. Keabsahan data penelitian dilakukan dengan cara membandingkan kekonsistenan jawaban dari subjek penelitian pada setiap item pertanyaan dari metode wawancara dan kuesioner terbuka. Bila terjadi kekonsistenan jawaban, maka data dinyatakan absah. Setelah data pada item pertanyaan tertentu dinyatakan absah, kemudian dilanjutkan pengecekan keabsahan data pada jawaban item berikutnya. Data penelitian dapat dinyatakan tidak absah, bila setelah pengecekan keabsahan data dengan triangulasi metode ditemukan ketidakkonsistenan jawaban dari subjek penelitian pada item tertentu. Data penelitian yang telah dinyatakan tidak absah, maka data penelitian tidak digunakan dalam berikutnya. 
Langkah-langkah penelitian ini meliputi observasi awal, studi literatur, perencanaan penelitian, pelaksanaan penelitian, analisis data, pembahasan hasil, dan penarikan kesimpulan. Langkah penelitian ini dapat dicermati pada diagram alir gambar 2.

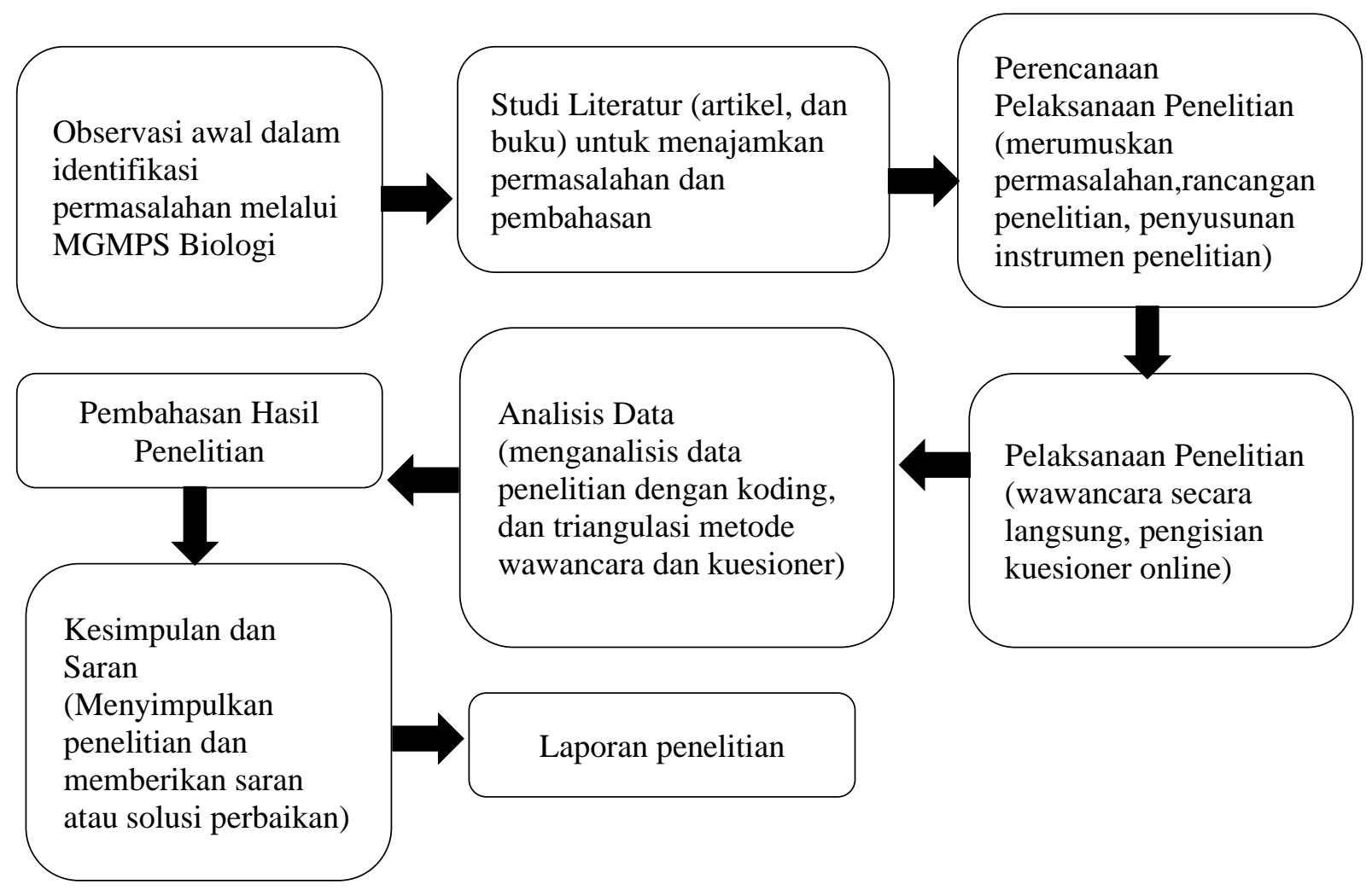

Gambar 2. Diagram Alir Penelitian

\section{HASIL DAN PEMBAHASAN}

Pembelajaran daring atau pembelajaran jarak jauh di sekolah tingkat SMA suatu hal baru. Pembelajaran ini sebagai alternatif pengganti pembelajaran tatap muka saat wabah Covid-19. Oleh karena itu, persepsi yang benar tentang pembelajaran daring dan/atau pembelajaran jarak jauh sangat penting bagi pengampu kebijakan kepentingan, lembaga pendidikan, dan pelaksana pendidikan. Dalam menyelesaikan pertanyaan tentang persepsi pembelajaran daring, AK menjelaskan bahwa pembelajaran daring merupakan pembelajaran yang menggunakan jaringan internet dengan Learning Manajemen System (LMS). Begitu pula dengan SF, juga menjelaskan hal yang sama dengan menegaskan pembelajaran daring termasuk pembelajaran online. Berikut petikan hasil wawancara (W) dengan AK dan SF dan hasil isian kuesioner terbuka dari SF.

PE01 : Saat era musibah Covid-19 pembelajaran tatap muka berubah menjadi pembelajaran Daring, menurut bapak/Ibu apa pembelajaran Daring itu?

WPEOIAK : Pembelajaran dengan menggunakan jaringan internet, baik dengan LMS atau aplikasi sosmed

WPEO1SF : pembelajaran daring yaitu pembelajaran dimana proses pembelajarannya itu menggunakan jaringan dalam hal ini itu jaringan internet. Oleh karena itu, pembelajaran ini tidak tatap muka langsung alias harus menggunakan jaringan tadi itu.

KPEO1SF : Pembelajaran yang memanfatkan jaringan/ Internet sehingga pembelajaran ini juga disebut pembelajaran online

Kejelasan pemahaman antara pembelajaran daring dan pembelajaran jarak jauh dapat mempengaruhi pelaksanaan pembelajaran. Dalam menyelesaikan pertanyaan tentang kesamaan dan ketidaksamaan antara pembelajaran daring dan pembelajaran jarak jauh, SF menyatakan bahwa pembelajaran daring dapat dilaksanakan saat pembelajaran tatap muka dan juga saat pembelajaran 
jarak jauh dengan syarat pelaksanaan pembelajaran tersebut harus menggunakan jaringan internet. Berikut ini petikan wawancara (W) dan isian kuesiner (K) terbuka dengan SF.

PE02 : Apakah pembelajaran daring itu sama dengan pembelajaran jarak jauh (PJJ)?

WPEO2SF : Menurut saya pembelajaran daring dan PJJ (pembelajaran jarak jauh), ini serupa. Artinya ada kemiripan. Akan tetapi daring itu sebenarnya juga bisa tidak jarak jauh, artinya tatap muka langsung juga bisa dengan arti guru atau murid itu menggunakan jaringan internet itu. Jadi, PJJ ini otomatis menurut saya adalah termasuk pembelajran online atau menggunakna jaringan itu. Jadi, ya sama.

KPE02SF : Menurut saya tidak selalu karena dengan tatap muka juga bisa menggunakan daring dan daring juga bisa dikatakan pembelajaran jarak jauh.

Berdasarkan hasil penelitian menunjukkan bahwa guru biologi sudah memiliki persepsi yang benar terkait pembelajaran daring. Pembelajaran daring merupakan proses pembelajaran menggunakan komputer, laptop, dan handphone/android dengan memanfaatkan jaringan internet dalam kelas maya/ virtual sebagai upaya interaksi pembelajaran antara siswa dengan guru (Tesniyadi, 2018). Kemajuan perkembangan teknologi sangat berpengaruh dalam pelaksanaan dan keberhasilan proses pembelajaran daring dengan jarak jauh. Pada pelaksanaan pembelajaran daring dengan jarak jauh juga menemui beberapa kendala, diantaranya penumpukan tugas siswa, gangguan jaringan internet, dan kemunculan rasa malas atau kejenuhan (Hidayah et al., 2020). Keberhasilan proses pembelajaran daring dengan jarak jauh tergantung pemenuhan terhadap tiga syarat, yakni a) ketersediaan jaringan internet yang digunakan dalam proses pembelajaran, b) ketersediaan fasilitas bagi peserta didik, dan c) tersedianya tutor yang mampu mendampingi belajar dan mengatasi kesulitan dalam pembelajaran (Mustofa et al., 2019).

Pembelajaran jarak jauh membutuhkan perencanaan. Perencanaan pembelajaran jarak jauh harus mencakup tujuan, metode, media, materi, kegiatan pembelajaran, dan penilaian pembelajaran. Hasil wawancara dengan SF menyatakan bahwa pelaksanaan pembelajaran daring dengan jarak jauh harus menyusun rencana pelaksanaan pembelajaran (RPP) dengan menyesuaikan kondisi di masa Covid-19. Begitupula hasil pengisian kuesioner terbuka dari AK dan bahkan SF, menyatakan bahwa RPP daring juga harus berisi langkah pembelajaran, materi, alokasi waktu, dan metode pembelajaran. Berikut ini cuplikan hasil wawancara deng SF dan pengisian kuesiner terbuka dari AK dan SF.

PERO1 : pembelajaran daring membutuhkan perencanaan, apakah setiap akan melaksanakan pembelajaran, bapak/ibu menyusun RPP?

WPERO1SF : untuk pembelajaran jarak jauh atau daring di masa pandemi covid ini, kita sebagai guru tetap menyusun RPP, akan tetapi ada beberapa yang menyesuaikan kondisi seperti alokasi waktu, kemudian materi yang disampaikan ini juga harus dipersiapkan. Misalnya dengan memberikan gambaran-gambaran atau ilustrasi berupa video dan juga bisa menggunakan ringkasan-ringkasan materi berupa PPT

KPEROIAK : Ya

KPER01SF : Ya menyusun RPP karena dengan adanya RPP kita bisa melakukan langkah langkah pembelajaran, menyiapkan materi, alokasi waktu, metode dan model pembelajaran apa yang sesuai dengan materi

Hasil penelitian juga dapat menguatkan bahwa subjek penelitian dalam melaksanakan pembelajaran daring dengan jarak jauh sudah menyusun perencanaan pelaksanaan pembelajaran. Perencanaan pelaksanaan pembelajaran merupakan salah satu tahap persiapan subjek penelitian dalam mengajar. Perencanaan ini dapat menopang keberhasilan dalam melaksanakan pembelajaran. Keberhasilan pembelajaran daring dengan jarak jauh tergantung pada kemampuan guru dalam merancang dan melaksanakan pembelajaran, baik metode, media pembelajaran, dan pelaksanaan pembelajaran yang menarik dan inovatif. Karena pendidikan yang berkualitas itu tergantung pada keberhasilan guru dalam merancang dan melaksanakan pembelajaran yang memupuk kemandirian siswa yang kondusif (Oktavian \& Aldya, 2020). Perencanaan pembelajaran harus memenuhi beberapa komponen minimal yang telah disederhanakan dengan RPP satu lembar oleh Nadiem Makarim, Menteri Pendidikan dan Kebudayaan RI, yakni, Identitas, alokasi waktu, kelas, tujuan pembelajaran, metode pembelajaran, langkah/ kegiatan pembelajaran, dan penilaian. Akan tetapi 
bisa ditambah dengan memuat jenis media pembelajaran dan sumber belajar. Sejalan dengan hal itu, hasil penelitian yang dilakukan Jefri Dolong, penyusunan program pengajaran harus sesuai dengan konsep pendidikan dan pengajaran yang ditetapkan oleh kurikulum (Dolong, 2016).

Kemudahan dan kesulitan yang dijumpai guru saat penyusunan RPP itu wajar terjadi. Oleh karena itu, dalam menyelesaikan pertanyaan tentang kesulitan yang dihadapi guru dalam merencanakan pelaksanaan pembelajaran jarak jauh, AK dan SF dalam wawancara menyatakan bahwa kesulitan dalam merencanakan pembelajaran daring adalah pertama, alokasi waktu. AK menyatakan alokasi waktu terbatas dalam mempersiapkan atau mencari media, dan materi yang dicantumkan di RPP dan yang akan diberikan ke siswa melalui platform whatsapp (WA) dan/atau google classroom. AK dalam pengisian kuesioner terbuka menyatakan, bahwa waktu yang dibutuhkan menyiapkan materi yang sesuai lebih lama dibandingkan saat pembelajaran tatap muka. Sementara SF dalam wawancara menyatakan alokasi waktu pembelajaran daring diperpendek dari kondisi normal. Kedua, kesulitan mencari media dan sumber belajar yang sesuai dan efektif dengan waktu yang terbatas, sehingga AK dalam wawancara menyatakan sudah harus membagikan media pembelajaran ke siswa, walupun belum pas atau sesuai. Begitupula SF, dalam wawancara diketahui bahwa mencari sumber penunjang pembelajaran video yang efektif dalam menjelaskan materi seefesien mungkin menjadi bagian kesulitan. Ketiga, jaringan internet. Jaringan internet bagian kesulitan pada daerah jauh dari perkotaan, SF dalam wawancara menyatakan mengeksploirasi sumber penunjang sumber belajar membutuhkan internet yang kadang-kadang trouble. Berikut ini petikan hasil wawancara dengan AK dan SF dan pengisian kuesioner terbuka dari AK dan SF.

PER07 : Dalam penyusunan rencana pembelajaran daring baik dari metode atau model, media, platform pembelajaran. kesulitan atau kendala yang bapak/ibu alami dalam menyusun rencana pembelajaran daring? Bagaimana penjelasannya?

WPEROTAK : kesulitannya itu waktunya. Karena waktunya terbatas, sehingga belum sempat mencari yang pas itu sudah harus segera dikirim ke anak. Sehingga karena mendesak kadang saya kirim gambar yg kurang sesuai dengan kebutuhan anak. Platform WA, Google classroom, google form digunakan karena sudah biasa digunakan oleh siswa. Kalau pakai seperti quiper itu bisa tapi anak itu aplikasinya tidak punya hanya sebagian yang punya, sehingga tidak bisa menggunakan itu. Tapi kalau google form, classroom ratarata anak sudah biasa menggunakan, saya juga sebagai guru menyesuaikan dengan kondisi siswa.

WPERO7SF : Kendala-kendala yang sementara ini saya temukan adalah alokasi waktu. Dimana alokasi waktu PJJ ini lebih singkat dan kita dituntut untuk menyampaikan materi seefisien mungkin. Jadi hambatannya waktu. Kalau dalam menyusun rencana itu faktor utamanya adalah kesulitan mencari penunjang materi dalam hal ini adalah sumber sumber pembelajaran seperti video, kemudian menyusun PTT agar nanti yang kita sampaikan itu sesuai dengan harapan kurikulum. Maka pengambilan bahan ini, merupakan suatu hambatan menurut kami. Karena mencarinya adalah menggunakan internet atau menggunakan jaringan. Kadang-kadang dengan mencari itu hambatannya trouble dll.

KPER07AK : Mencari materi yang sesuai membutuh waktu yang lebih lama.

KPERO7SF : Internet/paket, kesiapan anak, $h$ p, dan mencari materi yang sesuai dengan alokasi waktu.

Hasil penelitian menunjukkan bahwa guru biologi mengalami kesulitan tahap perencanaan pembelajaran, yakni dalam ketersediaan waktu pembelajaran daring, karena alokasi waktu saat pembelajaran daring dikurangi. Sementara, konten materi biologi hanya dikurangi satu kompetensi dasar pada masa pandemi. Sehingga, guru merasa kesulitan dalam menentukan alokasi waktu pada setiap kompetensi dasar. Keterbatasan alokasi waktu juga berimplikasi pada kesulitan guru dalam merencanakan, mempersiapkan, atau mencari media pembelajaran yang efektif bagi siswa. Berkurangnya ketersediaan waktu pembelajaran daring juga menyebabkan kesulitan bagi guru biologi untuk memenuhi beban jam mengajar. Hal ini sejalan dengan penjelasan pemangku kebijakan terkait penyesuaian kebijakan pembelajaran di masa pandemi Covid-19 yang disosialisasikan pada 7 Agustus 2020, bahwa ada kendala waktu pembelajaran berkurang yang berdampak pada guru tidak mungkin memenuhi beban jam mengajar (Kemendikbud et al., 2020). 
Kesulitan guru biologi untuk perencanaan pembelajaran dalam mengeksplorasi dan menemukan media pembelajaran yang efektif bagi konten materi dan kondisi siswa. Media pembelajaran merupakan salah satu alat bantu dalam memperlancar proses pembelajaran dan sekaligus sebagai salah satu sumber belajar bagi siswa (Utama, 2020). Pemilihan media pembelajaran yang tepat itu dapat merangsang siswa kreatif, aktif, dan menyenangkan dalam meraih tujuan pembelajaran (Sultan \& Tirtayasa, 2019). Media pembelajaran online sangat banyak tersedia secara online, baik berupa e-book, gambar, dan video pembelajaran. Hanya saja, guru biologi mengalami kesulitan dalam memilih dan memilah gambar dan video pembelajaran yang tepat dan efektif dalam mewakili alur penyampaian materi sesuai keinginannya. Hal ini sejalan dengan penelitian tentang kesulitan memilih media pembelajaran yang cocok dengan metode pembelajaran (Putri \& Citra, 2019).

Pelaksanaan Pembelajaran jarak jauh merupakan penerapan dari rencana pelaksanaan pembelajaran daring yang telah dirumuskan sebelumnya. Platform whatsapp (WA) dan google classroom (GC) yang digunakan dalam pembelajaran jarak jauh dan platform google form untuk penilaiannya. Dalam menyelesaikan pertanyaan terkait jenis platform yang digunakan saat pembelajaran daring, AK dalam wawancara menyatakan dengan menggunakan whatsapp (WA), karena semua siswa familier dan memiliki aplikasi sosmed ini. Begitupula dengan SF, dalam wawancara juga menggunakan kelas maya WA dan Google classroom, karena siswa mudah menggunakannya dan bisa dipadu dengan google form. Berikut ini cuplikan wawancara dengan AK dan SF.

PELO1 : Apa jenis platform pembelajaran yang bapak/ibu gunakan dalam pembelajaran daring atau PJJ? Kenapa?

WPELO1AK : WA yang saya gunakan dalam pembelajaran daring, karena semua siswa sudah memiliki dan biasa menggunakannnya.

WPELOISF : adalah google classroom dan kelas WA. Saya pilih itu karena menurut saya itu mudah, anak-anak juga mudah untuk memahami dan dalam google classroom itu memang sudah ada kumpulan materi, kemudian disertai dengan soal dan kunci jawabannya dan kita tinggal menyusun sesuai dengan bab yg kita inginkan.

Penerapan pembelajaran melalui kelas maya whatsapp dan google classroom ada kesulitan yang dihadapi guru. Dalam menyelesaikan pertanyaan terkait kesulitan yang dijumpai saat menggunakan kelas maya WA dan GC, SF dalam wawancara menyatakan bahwa kesulitan berpangkal pada siswa, yakni keaktifan siswa dan paketan. Beranekaragam latar belakang siswa menyebabkan tingkat keaktifan dan kedisiplinan dalam belajar juga berbeda. Berikut petikan wawancara dengan SF

PELO2 : Apa kesulitan yang bapak/ibu hadapi dalam melaksanakan jenis platform pembelajaran daring?

WPELO2SF : dalam menyusun atau melaksanakan PJJ dengan menggunakan google classroom atau kelas WA ini adalah kendalanya yang pertama adalah siswa. Dimana siswa kita ini, berbagai macam latar belakang. Dengan latar belakang itu, keaktifan mereka sulit untuk dikendalikan karena tidak bertemu langsung. Kemudian hambatannya adalah jaringan atau pulsa atau juga paketan. Dimana kadang-kadang anak-anak itu terhambat adanya paketan atau jaringan itu, mungkin karena trouble juga merupakan hambatan

Kesulitan guru juga terjadi saat penggunaan media pembelajaran baik berupa video, PPT, dan lembar kerja siswa (LKS), yakni terletak pada keaktifan siswa. Hal ini seperti yang dinyatakan SF saat wawancara, bahwa keterlambatan siswa masuk kelas maya dan respon siswa menjadi hambatan tersendiri dalam pembelajaran. Sebagian mereka beralasan ketiduran tidak ada yang membangunkannya, paketan kosong, dan jaringan trouble. Berikut ini cuplikan wawancara dengan SF.

PEL04 : Apa kesulitan yang bapak/ibu hadapi dalam menentukan dan menggunakan jenis media pembelajaran daring?

WPELO4SF : pada saat menggunakan media pembelajaran seperti video, ppt, dan lk itu kendalanya adalah keaktifan anak. Dimana kadang-kadang keaktifan anak ini merupakan hambatan. Karena kadang-kadang anak itu sudah waktunya, ada yang masih belum masuk kelas 
atau masih belum mengikuti kegiatan pembelajaran daring, kemudian hambatan yang berikutnya setelah saya cek pada anak-anak itu macam-macam ada yang bilang tidak ada yang membangunkan kemudian kadang-kadang paket. Jadi, hamabatn proses ini adalah anak. Selain anak tadi adalah hambatan kita adalah paketan atau jaringan yg tersedia.

Metode pembelajaran jarak jauh menggunakan ceramah dan tanya jawab melalui aplikasi WA dan metode inquiri learning dan based learning. Dari hasil wawancara dengan AK dan SF, ditemukan kesulitan yang ditemui saat melaksanakan metode tersebut. AK menyatakan metode ceramah dan tanya jawab melalui voice note $(\mathrm{VN})$ pada aplikasi WA membutuhkan waktu lebih lama, yakni saat guru VN dan siswa mendengarkan VN, sehingga waktu tanya jawab berjalan relatif sebentar dan habis waktu pembelajarannya. Sedangkan SF menyatakan hal serupa saat menerapkan metode inquiri learning dan based learning dengan menambah kesulitan keaktifan siswa. Berikut ini cuplikan wawancara dengan AK dan SF.

PELO5 : Dalam melaksanakan metode pembelajaran dalam pembelajaran daring, apa kesulitan yang bapak hadapi dalam menerapkan metode pembelajaran tersebut?

WPELOSAK : Pelaksanaan metode ceramah dan tanya jawab mengalami kesulitan dalam VN, karena untuk VN sendiri membutuhkan waktu dan anak juga butuh waktu mendengar dan saat tanya jawab waktunya tinggal sedikit, sehingga siswa yang aktif juga sedikit.

WPELO5SF : pada saat kita menggunakan metode pembelajaran inquiri learnng, based learning atau yang lain ada beberapa hambatan yg kami hadapi pada saat melakukan daring ini, $d$ iantaranya hambatan itu adalah penggunaan waktu. Karena waktu yang biasa dalam proses pembelajaran sebelum Covid itu lebih lama atau lebih leluasa. Dengan adanya PJJ ini waktu itu akan dimaksimalkan seefisien mungkin. Karena waktu ini akan terus terang dikurangi durasinya oleh pihak sekolahan untuk menyesuaikan kondisi. Sehingga waktu inilah yang menurut saya adalah menjadi hambatan. Selain itu, juga keaktifan anak.

Pelaksanaan pembelajaran merupakan proses timbal balik antara guru dan siswa. Oleh karena itu, dalam pelaksanaan pembelajaran jarak jauh juga harus ada keaktifan siswa dan guru sebagai hubungan timbal baliknya. Dalam menyelesaikan pertanyaan tentang kesulitan mengontrol keaktifan siswa dalam pelaksanaan pembelajaran, AK dalam wawancara menyatakan bahwa dalam pembelajaran jarak jauh ini mengalami kesulitan mengontrol dan memotivasi keaktifan siswa, bahkan sudah dipanggil namanya pada kelas maya WA dan GC tetap masih ada siswa yang tidak memberikan respon dan komentar dalam pembelajaran. SF juga menyatakan bahwa mendapati kesulitan membangun komunikasi dengan siswa yang tidak aktif di kelas WA dan GC, walaupun sudah diberikan motivasi dan disapa di kelas maya. Berikut ini petikan wawancara dengan AK dan SF.

PEL06 : Pembelajaran daring juga harus ada aktifitas siswa dalam pembelajaran, apa kesulitan yang bapak/ibu jumpai dalam memantau aktifitas belajar siswa dalam KBM Daring?

WPELO6AK : untuk mengaktifkan siswa itu sudah saya beri pertanyaan sudah saya panggil anak yang belum pernah komentar tapi dia juga tetap tidak berkomentar di grup wa. Terus dalam perasaan saya apakah anak itu tidak berkomentar itu bisa atau tidak bisa. Sulit untuk memahami anak mengerti atau tidak. Seakan-akan yang berkomentar itu yang aktif dan yang tidak berkomentar itu tidak aktif.

WPELO6SF : yang sering saya temukan dalam proses pembelajaran itu, adalah sekali lagi tentang komunikasi dengan anak baik pada saat kita menggunakan kelas wa maupun google classroom ini memang ada beberapa anak saja yang aktif, atau katakanlah anak itu ada yang aktif tapi hanya orang-orang yang tertentu saja. Ada beberapa anak yang kurang aktif itu kita bangkitkan atau kita dorong atau kasih motivasi dengan berbagai macam cara misalnya dipantau setiap beberapa menit " ayo anak-anak yang belum absen, yang belum mengerjakan ini"

Kesulitan yang menonjol didapati guru saat pembelajaran daring jarak jauh, tentunya ada kesulitan yang menonjol dari kesulitan yang lain. Dalam menyelesaikan pernyataan tentang kesulitan yang menonjol saat pembelajaran daring dengan jarak jauh, AK dalam pengisian kuesioner terbuka menyatakan mengontrol aktivitas siswa. Begitupula dengan SF saat wawancara dan pengisian kuesioner terbuka juga menyatakan, bahwa kesulitan yang paling menonjol ditemui 
saat pembelajaran daring ini adalah keaktifan siswa bagi siswa yang pasif. Berikut ini petikan pengisian kuesioner dan wawancara dengan AK dan SF.

PEL09 : Dalam pelaksanaan pembelajaran daring, apa kesulitan yang paling menonjol yang bapak/ibu hadapi diantara metode, media, mengontrol aktifitas siswa, dan penjelasan guru?

KPELO9AK : Mengontrol aktivitas siswa

KPELO9AK : Keaktifan siswa

WPELO9SF : yang paling menonjol kesulitannya adalah tentang keaktifan siswa. Karena letak siswa berjauhan, kemudian latar belakangnya macam-macam maka menurut saya adalah tentang siswa dan siswa ini memang sudah kita ketahui karakternya ada yang aktif ada yang pasif. Nah yang pasif inilah yang menjadi hambatan kita, jadi yang paling menonjol kesulitannya adalah siswa yang pasif. Hambatannya ya keaktifan siswa itu.

Ciri khas pembelajaran daring dengan jarak jauh itu bertumpu utama pada kelancaran jaringan internet. Oleh karena itu, kesulitan jaringan internet dapat menghambat secara total perencanaan dan pelaksanaan pembelajaran daring. Guru biologi mengalami kesulitan jaringan internet, terutama pada daerah yang secara geografis jaringan internet yang tidak stabil. Hal ini sejalan dengan hasil penelitian yang menyimpulkan bahwa salah satu kesulitan guru dalam melaksanakan pembelajaran daring adalah gangguan jaringan internet (Santosa \& Marina, 2020).

Kesulitan guru biologi dalam pembelajaran daring dengan jarak jauh adalah mengontrol aktifitas siswa dalam pembelajaran. Karena pembelajaran daring yang tidak menggunakan aplikasi conferensi zoom, google meet, dan lainnya tidak bisa melakukan tatap muka secara virtual. Sehingga aktivitas siswa dapat dilihat pada saat siswa merespon pertanyaan atau tanya jawab, dan saat mengumpulkan tugas. Sementara bagi siswa yang pasif, maka bagi guru tidak bisa mengontrol aktifitas siswa saat pembelajaran daring. Hal ini sejalan dengan penelitian yang menghasilkan temuan kesulitan guru saat siswa tidak mengumpulkan tugas pada pembelajaran daring (Karmala, 2021).

Penilaian pengetahuan, keterampilan, dan sikap pada pembelajaran daring juga dilakukan secara online. Dalam menyelesaikan pertanyaan tentang kesulitan yang dijumpai saat melakukan penilaian secara online, SF dalam wawancara menyatakan bahwa penilaian online yang paling sulit adalah penilaian sikap kejujuran siswa. Sikap kejujuran ini berimplikasi pada penilaian pengetahuan, yakni siswa yang tidak atau kurang aktif dalam pembelajaran dan tugas justru memiliki perolehan nilai pengetahuan yang lebih tinggi dibandingkan yang aktif. Hal ini juga terjadi pada perolehan nilai keterampilan. Maka mendorong praduga apakah ada yang membantu mengerjakannya atau bahkan dikerjakan orang lain?. Berikut cuplikan wawancara dengan SF.

PENO3 : Dalam penilaian hasil belajar siswa yang berupa pengetahuan (tugas, ulangan harian) dan keterampilan, apa kesulitan yang bapak jumpai dalam penilaian tersebut?

WPENO3SF : hambatan kita dalam melakukan penilaiaan itu adalah tentang kejujuran anak. Karena jarak jauh, jadi kejujuran anak ini sulit dipantau. Kemudian kadang-kadang anak itu memiliki kelebihan di bidang skill, pengetahuannya tidak begitu menonjol. Kadang kita sebagai guru kebanyakan hanya melihat di pengetahuan padahal belum tentu di dua penilaian berikutnya dia jelek. Jadi kadang anak itu di vonis jika nilai pengetahuannya jelek maka anak itu kurang berhasil dalam pendidikan. Bahkan perolehan nilai pengetahuan siswa yang kurang aktif lebih bagus dibandingkan siswa yang aktif. Dalam keterampilan juga mengalami kesulitan, karena dalam laporan videonya ketika salah bisa dibetulkan lagi, berulangkali ketika sudah benar baru dikirim, ada anak yang seperti $i t u$.

Saat pembelajaran daring berjalan atau setelah selesai satu kompetensi dasar, maka guru biologi melakukan evaluasi atau penilaian pembelajaran secara daring dengan aplikasi google form. Guru biologi mendapati kesulitan dalam melakukan penilaian atau evaluasi pembelajaran. Hal ini sejalan dengan penelitian yang menemukan kesulitan guru dalam melakukan evaluasi pembelajaran pada pembelajaran berbasis online (Ariesca et al., 2021). Guru biologi mengalami kesulitan dalam melakukan penilaian sikap, terutama sikap kejujuran siswa saat berlangsungnya penilaian. Kesulitan mengontrol kejujuran siswa saat penilaian dapat menyebabkan ketidak akuratan penilaian 
yang dilakukan guru. Kesulitan ini sejalan dengan penelitian yng menghasilkan temuan bahwa dalam pembelajaran daring, guru mengalami kesulitan dalam penilaian sikap (Ramdhayani et al., 2020).

\section{KESIMPULAN}

Penelitian ini dapat disimpulkan bahwa kesulitan guru biologi dalam pembelajaran daring dengan jarah jauh meliputi tiga tahapan. Pertama, tahap perencanaan pembelajaran. Kesulitan guru pada tahap ini adalah a) keterbatasan alokasi waktu, b) mempersiapkan media pembelajaran yang efektif, c) gangguan atau terkendala jaringan internet saat mempersiapkan pembelajaran. Kedua, tahap pelaksanaan pembelajaran. Kesulitan guru pada tahap ini adalah a) memantau dan mengontrol aktivitas siswa dalam pembelajaran daring, b) membangun komunikasi dengan siswa yang pasif saat pembelajaran daring. Ketiga, tahap penilaian pembelajaran. Kesulitan guru pada tahap ini adalah a) penilaian sikap, terutama kejujuran dalam mengikuti atau menyelesaikan penilaian pembelajaran, b) penilaian keterampilan yang tidak ideal.

Berdasarkan kesimpulan penelitian yang telah dilakukan, perlu adanya penelitian lanjutan tentang upaya mengatasi kesulitan pembelajaran jarak jauh yang meliputi tiga tahap, yakni tahap perencanaan, pelaksanaan, dan penilaian pembelajaran.

\section{DAFTAR PUSTAKA}

Anggianita, S., Yusnira, Y., \& Rizal, M. S. (2020). Persepsi Guru terhadap Pembelajaran Daring di Sekolah Dasar Negeri 013 Kumantan. Journal of Education Research, 1(2), 177-182. https://doi.org/10.37985/joe.v1i2.18.

Anugrahana, A. (2020). Hambatan, Solusi dan Harapan: Pembelajaran Daring Selama Masa Pandemi Covid-19 Oleh Guru Sekolah Dasar. Scholaria: Jurnal Pendidikan dan Kebudayaan, 10(3), 282-289. https://doi.org/10.24246/j.js.2020.v10.i3.p282-289.

Ariesca, Y., Dewi, N. K., \& Setiawan, H. (2021). Analisis Kesulitan Guru Pada Pembelajaran Berbasis Online di Sekolah Dasar Negeri Se-Kecamatan Maluk Kabupaten Sumbawa Barat. Progres Pendidikan, 2(1), 20-25. https://doi.org/10.29303/prospek.v2i1.86.

Budiaman, B. (2017). Analisis Faktor-Faktor Kesulitan Penerapan E-Learning Dalam Pembelajaran IPS. Jurnal Sejarah Lontar, 7(2), 50. https://doi.org/10.21009/lontar.072.05

Dolong, J. (2016). Sudut Pandang Perencanaan dalam Pengembangan Pendidikan. Jurnal Inspirasi Pendidikan, 1(1), 65-76.

Gulo, W. (2002). Metodelogi Penelitian. Jakarta: Gramedia Widiasarana Indonesia.

Handoyo. (2020). Wabah Virus Corona Ancam Pendidikan 300 Juta Siswa. 6 Maret 2020. https://internasional.kontan.co.id/news/unesco-wabah-virus-corona-ancam-pendidikan300-juta-siswa.

Hidayah, A. A. F., Al Adawiyah, R., \& Mahanani, P. A. R. (2020). Efektivitas Pembelajaran Daring di Masa Pandemi Covid 19. JURNAL SOSIAL: Jurnal Penelitian Ilmu-Ilmu Sosial, 21(September), 53-56. http://sosial.unmermadiun.ac.id/index.php/sosial/article/view/61.

Hutauruk, A., \& Sidabutar, R. (2020). Kendala Pembelajaran Daring Selama Masa Pandemi di Kalangan Mahasiswa Pendidikan Matematika: Kajian Kualiatatif Deskriptif. Journal of Mathematics Education and Applied, 02(01), 45-51.

Karmala, F. S. (2021). Analisis Faktor-Faktor Kesulitan Guru PL dalam Pembelajaran Daring di 
SMP N 1 Kecamatan Gunuang Omeh. 5, 73-78.

Kemendikbud. (2018). Pemerintah Terus Upayakan Pemenuhan Kebutuhan Dasar Masyarakat di $\begin{array}{llll}\text { Bidang Pendidikan. } & 10 & \text { November } & \end{array}$ https://www.kemdikbud.go.id/main/blog/2018/11/ pemerintah-terus-upayakanpemenuhan-kebutuhan-dasar-masyarakat-di-bidang-pendidikan.

Kemendikbud, Kemenag, \& SatgasCovid. (2020). Penyesuaian Kebijakan Pembelajaran di Masa Pandemi Covid-19.

Jayanti, L.D. (2020). Kendala Pembelajaran Daring Guru Sekolah Dasar di Kabupaten Banjarnegara. 21(1), 1-9. http://journal.um-surabaya.ac.id/index.php/JKM/article/view/ 2203.

Mastura, \& Santaria, R. (2020). Dampak Pandemi Covid-19 terhadap Proses Pengajaran bagi Guru dan Siswa. Jurnal Studi Guru dan Pembelajaran, 3(2), 634.

Mendikbud. (2020). Surat edaran Mendikbud: Pembelajaran secara daring dan bekerja dari rumah dalam rangka pencegahan penyebaran corona virus disease (COVID-19). (4 Tahun 2020).

Mustofa, M. I., Chodzirin, M., Sayekti, L., Negeri, U. I., \& Semarang, W. (2019). Formulasi Model Perkuliahan Daring Sebagai Upaya Menekan Disparitas Kualitas Perguruan Tinggi (Studi terhadap Website pditt.belajar.kemdikbud.go.id). Walisongo Journal of Information Technology, 1(2), 151-160.

Oktavian, R., \& Aldya, R. F. (2020). Efektivitas Pembelajaran Daring Terintegrasi di Era Pendidikan 4.0. Didaktis: Jurnal Pendidikan dan Ilmu Pengetahuan, https://doi.org/10. 30651/didaktis.v20i2.4763.

Priyono. (2008). Metode Penelitian Kuantitatif. Sidoarjo: Zifatama Publishing.

Putri, S. D. W. I., \& Citra, D. E. K. A. (2019). Problematika Guru Dalam Menggunakan Media Pembelajaran Pada Mata Pelajaran IPS di Madrasah Ibtidaiyah Darussalam Kota Bengkulu. 1.

Raco, J. (2018). Metode Penelitian Kualitatif: Jenis, Karakteristik, dan Keunggulannya. https://doi.org/10.31219/osf.io/mfzuj.

Radarcirebon. (2020). 60 Persen Guru Kesulitan PJJ. https://www.radarcirebon.com/2020/10/24 /60-persen-guru-kesulitan-pjj/.

Ramdhayani, E., Noviati, W., Syafruddin, Deniati, L., \& Kurniati, E. (2020). Analisis Penilaian Sikap Siswa Biologi Selama Pembelajaran Daring Pada Era Tatanan Baru. Jurnal Pendidikan, 10(Alifah 2019), 2017-2020. http://repository.lppm.unila.ac.id/25678/.

Sadikin, A., \& Hamidah, A. (2020). Pembelajaran Daring di Tengah Wabah Covid-19. Biodik, 6(2), 109-119. https://doi.org/10.22437/bio.v6i2.9759.

Sae, D. B., \& Sihotang, H. (2020). Analisis Hambatan Guru MIPA dalam Pembelajaran Daring di SMAS KR. Rantepaodi Masa Pandemi Covid 19. 1(1), 1-12.

Santosa, T. A., \& Marina, E. (2020). Analisis Masalah Pendidikan Biologi Pada Sekolah Menengah 
Pertama Di Era Pandemi Covid -19. Jurnal Review Pendidikan dan Pengajaran, 3(2), 273-278.

Sari, N. (2020). Problematika Pelaksanaan Pembelajaran Daring masa Pandemik Covid-19 di MIN 3 Medan. Journal Of Education And Teaching Learning (JETL), 2(3), 44-57. https:// doi.org/10.51178/jetl.v2i3.67.

Satgas-Covid-19. (2021). Peta Persebaran Covid-19. 23 Januari 2021. https://covid19.go.id/petasebaran.

Siyoto, S., \& Sodik, M. A. (2015). Dasar Metodologi Penelitian Dr. Sandu Siyoto, SKM, M.Kes M. Ali Sodik, M.A. 1. Dasar Metodologi Penelitian, 1-109.

Sultan, U., \& Tirtayasa, A. (2019). Pentingnya Media Pembelajaran Berbasis Video Untuk Siswa Komunikasi Verbal Media Visual Daya ingat (\%) 3 Jam. 2(1).

Tesniyadi. (2018). Pengelolaan Pendidikan. Yogyakarta: Samudera Biru.

Utama, G. S. (2020). Pentingnya Memilih Media Yang Tepat Dalam Pembelajaran. Pena Rumah Belajar. http://pena.belajar.kemdikbud.go.id/2020/10/pentingnya-memilih-media-yangtepat dalam- pembelajaran/.

WHO. (2020). COVID-19 Weekly Epidemiological Update. World Health Organization, November, 1;4. https://www.who.int/docs/default-source/coronaviruse/situationreports/20 201012-weekly-epi-update-9.pdf. 